\title{
Türkiye’de Ekonomik Büyüme ve Enflasyon İlişkisi ${ }^{1}$
}

\author{
Şahin KARABULUT*
}

ÖZ

Ülkelerin en önemli makroekonomik hedeflerinden birisi olan ekonomik büyümenin sağlanması için uygulanan politikalar ekonomideki bazı unsurlarda zaman zaman bozulmalara yol açabilmektedir. Bu nedenle ekonomik büyüme ile enflasyon arasında bir ilişki olup olmadığı uygulanacak ekonomi politikaları açısından yol gösterici olacaktır. Bu amaçla çalışmada, Türkiye ekonomisi için 2003:Q1-2018:Q1 döneminde ekonomik büyüme ve enflasyon arasındaki ilişki analiz edilmiştir. Yapılan Granger nedensellik testi sonucunda yüzde 5 anlamlılık seviyesinde GSYİH'nın enflasyonun nedeni olduğu sonucuna ulaşılmış ancak enflasyondan GSYİH'ya doğru bir nedensellik ilişkisi tespit edilememiştir. Diğer yandan, yapılan birim kök testi sonucunda GSYİH ve enflasyona ait serilerin düzey değerlerinde durağan olmadıkları ve birinci dereceden farkı alındığında durağan hale geldikleri tespit edilmiştir. Durağan olmayan serilerle yapılan regresyon sonuçlarının sahte regresyona yol açması muhtemel olduğundan dolayı değişkenler arasında eşbütünleşme analizi yapılmış ancak herhangi bir eşbütünleşmeye rastlanılmamıştır. Bu da GSYİH ve enflasyon arasında uzun dönemli bir ilişkinin olmadığını ve serilerin uzun dönemde birbirinden bağımsız hareket ettiğini ortaya koymuştur.

Anahtar Kelimeler: Ekonomik Büyüme, Enflasyon, Granger Nedensellik.

JEL Sınıflandırması: O44, E31, H30

\section{Relation of Economic Growth and Inflation in Turkey}

\begin{abstract}
It is one of the most important macroeconomic objectives of ensuring the country's economic growth. However, these policies can sometimes lead to deterioration in some elements of the economy. For this reason, the relationship between economic growth and inflation is indicative of economic policy. In this respect, the relationship between economic growth and inflation in Turkey is examined for the period 2003:Q1-2018:Q1. As a result of the Granger causality test, it is concluded that GDP is the cause of inflation at a level of 5 percent significance, but a causality relationship from inflation to GDP has not been established. On the other hand, as a result of the unit root test, it is determined that the levels of GDP and inflation series are not stable and become stable when the first difference is taken. Regression results made with non-stationary variables can lead to spurious regression. For this reason, cointegration analysis was performed between the variables, but it has not been observed to any cointegration. This reveals that there is no long-term relationship between GDP and inflation and the series act independently of each other in the long-term.
\end{abstract}

Keywords: Economic Growth, Inflation, Granger Causality

JEL Classification: O44, E31, H30

Geliş Tarihi / Received: 19.10.2018 Kabul Tarihi / Accepted: 12.01.2019

\footnotetext{
${ }^{1}$ Bu çalışma, 12-16 Eylül 2018 tarihlerinde Çorum'da gerçekleştirilen "Uluslararası İnsan, Toplum ve Spor Bilimleri Sempozyumu"'nda sunulan sözlü bildirinin gözden geçirilmiş, düzenlenmiş ve genişletilmiş halidir.

* Arş. Gör. Dr., Karamanoğlu Mehmetbey Üniversitesi, İ̈BF, Maliye Bölümü, sahin-karabulut@hotmail.com, ORCID: 0000-0001-7955-6404.
} 


\section{GİRIŞ}

İktisat politikasının amaçları kaynak tahsisinde etkinlik, adil gelir dağılımı, ekonomik büyüme ve kalkınma, ekonomik istikrar ve ödemeler bilançosu dengesinin sağlanmasından oluşmaktadır. Ancak bu amaçlara ulaşmak için uygulanan politikalar bir amaca yaklaşırken zaman zaman diğer amaçtan uzaklaşılmasına neden olmakta ve bu durum literatürde amaç çatışması olarak ifade edilmektedir. Diğer yandan uygulanan ekonomi politikalarının birden fazla amaç üzerinde olumlu etki yapması da söz konusu olabilmektedir. Bu nedenle en önemli makroekonomik hedeflerden olan ekonomik büyüme ve fiyat istikrarının birbiriyle olan ilişkisinin belirlenmesi uygulanacak ekonomi politikalarına yol gösterici olması açısından oldukça önemlidir.

Enflasyon ve ekonomik büyüme arasındaki ilişkiye bakıldığında 1970'li yıllara kadar uygulanan Keynesyen politikalar çerçevesinde ağırlıklı olarak enflasyonun ekonomik büyüme açısından bir sorun oluşturmadığı görüşü hâkim olmuştur. Öyle ki, söz konusu yıllardaki hâkim görüş, Mundell ve Tobin gibi iktisatçılar tarafından savunulmuş ve sermaye birikiminin enflasyon sayesinde artarak ekonomik büyümenin artmasına neden olacağı dolayısıyla enflasyonun ekonomik büyümeyi pozitif etkileyeceği tezi ortaya koyulmuştur.

Genel olarak Keynesyen görüşü benimsemiş olan bazı iktisatçılar, enflasyonun bir dizi kanal aracılığıyla ekonomik büyümeye olumlu katkıda bulunduğuna inanmaktadır. Bu iktisatçıların savundukları temel argümanlardan birisi Keynes-Kaldor etkisi olarak da bilinen gelirin yüksek tasarruf eğilimi olanlar lehine yeniden dağıtılmasının tasarrufları artıracağı ve bunun da ekonomik büyümenin sağlanmasına neden olacağıdır. Ayrıca enflasyonist dönemlerde finansal getirilerin azalması nedeniyle yatırımların finansal sektörden reel sektöre kayması ve bu sayede sermaye birikiminin artacağı ifade edilmektedir (Tobin etkisi). Diğer yandan bu görüşü savunanlara göre enflasyonun varlığı ekonominin varlığını devam ettirebilmesi için zorunlu bir faktördür. $\mathrm{Bu}$ da enflasyonun ekonomik büyümenin kaçınılmaz bir parçası olduğunu göstermektedir. Son olarak da artan senyoraj veya enflasyon vergisi yoluyla zorunlu tasarruflar artırılacak ve ekonomik büyümenin sağlanmasında gerekli yatırımların yapılması için kamuya kaynak aktarımı sağlanacaktır (Chowdhury, 2002: 22).

1980'li y1llardan itibaren ise özellikle Latin Amerika'da yüksek enflasyon ve sinırlı ekonomik büyümenin aynı anda oluşmasıyla birlikte enflasyonun ekonomik büyüme üzerinde negatif etkisi olduğu görüşü hâkim olmaya başlamıştır. Temel olarak neoklasik okulun diğer ekonomistleri ise enflasyonun belirli nedenlerden dolayı ekonomik büyümeyi olumsuz yönde etkilediğine inanmaktadır. Bu görüşe göre enflasyon, gelecekteki kazanç hakkında belirsizliğe neden olur ve dolayısıyla yatırımları olumsuz etkiler. $\mathrm{Bu}$ da daha düşük yatırımlara ve dolayısıyla büyümeye yol açar. Diğer yandan enflasyon sektörlere göre fiyatlara farklı oranlarda yansıdığından dolayı, yatırım kararlarında bozulmaya ve kaynakların yanlış tahsisine neden olmaktadır. Ayrıca enflasyon, finansal varlıkların reel değerini düşürdüğü için, insanları değerli madenler veya gayrimenkul gibi reel varlıklar elde tutmaya teşvik etmektedir. Bu durum da finansal derinleşmeyi olumsuz etkilemektedir (Chowdhury, 2002: 22).

Ekonomik büyüme ve enflasyon ilişkisine yönelik görüşler bahsedildiği şekilde olmakla birlikte ekonomik büyüme ve kalkınma amacı kapsamında belirli bir seviyede sürekli ekonomik büyümenin sağlanması genellikle gelişmiş ülkelerin ağırlı verdiği bir hedef olarak bilinmektedir. Gelişmekte olan ülkeler ise daha çok ekonomik kalkınmanın sağlanmasını hedef almaktadır. Ayrıca geliş̧mekte olan ülkelerde piyasa dengesizlikleri çok fazla olduğundan dolayı fiyat istikrarının sağlanması oldukça güç olmaktadır. Türkiye de kurulduğu günden bu yana ekonomik büyüme ve kalkınma çabalarının yanı sıra sıklıkla enflasyonla mücadele etmek zorunda kalmıştır. Bu sebeple Türkiye ekonomisinde enflasyon ve ekonomik büyüme arasındaki ilişkinin tespit edilmesi önem arz etmektedir. 


\section{EKONOMIK BÜYÜME ILE ENFLASYON İLISSKISSINE YÖNELIKK YAKLAŞIMLAR VE AMPİRIK LITTERATÜR}

Toplumsal refah artışının sağlanabilmesi için enflasyon oranının düşürülerek fiyat istikrarının sağlanması ve ekonomik büyümenin devam ettirilmesi önemli makroekonomik hedeflerdendir. Ancak bu iki amacın birbirini kısa ve uzun dönemde etkileyip etkilemediği ya da bir etki söz konusu ise bu etkinin yönünün ne olduğu literatürde oldukça tartışma konusu olmuştur. Yapılan çalışmalardan bir kısmı ekonomik büyümenin enflasyondan olumsuz etkilendiğini ortaya koyarken bir kısmı ise, enflasyonun büyüme üzerinde pozitif etkisi olduğu sonucuna ulaşmıştır. Ağırlıklı olarak enflasyonun ekonomik büyüme üzerinde negatif etkisi olduğunu gösteren çalışmalardan bazıları ise enflasyonun belirli bir eşik değerin üstüne çıkması durumunda bu ilişkinin oluştuğunu ortaya koymaktadır. Bunlara ek olarak enflasyon ile ekonomik büyüme arasında anlamlı bir ilişki olmadığını savunan çalışmalar da mevcuttur. $\mathrm{Bu}$ nedenle ekonomik büyüme ve enflasyon arasındaki ilişkiye ilişkin literatür sonuçlarına göre gruplandırılarak incelenmiştir.

Özellikle İkinci Dünya Savaşı sonrasında yaşanan yüksek enflasyon oranları sonucunda ekonomik büyümenin bu durumdan nasıl etkilendiği tartışmaları gittikçe artmış ve söz konusu dönemde yaygın iktisadi anlayış olan Keynesyen görüşe göre enflasyonun bir risk teşkil etmediği ve ekonomik büyümenin fiyatlar genel seviyesindeki sürekli artışlardan pozitif etkilendiği kabul edilmiştir. 1970'lerdeki stagflasyonist sürecin ortaya çıkmasına kadar enflasyon ve ekonomik büyüme arasındaki pozitif ilişki varsayımı geçerliliğini korumuştur (Abel ve Bernanke, 2005: 435). Öyle ki, enflasyonun ekonomik büyüme üzerindeki pozitif etkisinin uzun dönemde dahi geçerli olacağı Tobin ve Sidrauski gibi ekonomistler tarafindan 1960'lı yıllar boyunca savunulmuştur (Bruno ve Easterly, 1996: 139). Fiyat artışları nedeniyle üreticinin elde ettiği kar oranlarında yaşanan artış sonucunda üretim ve istihdamda olumlu gelişmelerin ortaya çıkacağı fikrinden hareketle ekonomik büyümenin enflasyondan pozitif etkileneceğini savunan görüşlere bakıldığında bu argümanın temel dayanağının Phillips eğrisi olduğu görülmektedir. 1958 yılında A. Phillips tarafından 1861-1957 y1llarında İngiltere ekonomisinde işsizlik oranları ve nominal ücretlerden oluşan Phillips eğrisi oluşturulmuş ve işsizlik ile ücretler arasında negatif bir ilişki olduğu ortaya koyulmuştur. Söz konusu eğri Solow ve Samuelson (1960) tarafından geliştirilmiş ve enflasyonun nominal ücretlerden etkilendiği hesaba katılarak enflasyon ve işsizlik yani ekonomik büyüme arasında bir "değiş-tokuş" ilişkisi olduğu savunulmuştur. 
Tablo 1: Ekonomik Büyümenin Enflasyondan Pozitif Etkilendiğini Savunan Çalışmalar

\begin{tabular}{|c|c|c|c|c|}
\hline Yazar(lar) & Yll & Analiz dönemi & Yöntem & Sonuç \\
\hline Lucas & 1973 & $1951-1967$ & $\begin{array}{l}\text { En Küçük Kareler } \\
\text { (EKK) }\end{array}$ & $\begin{array}{l}\text { ABD gibi fiyat istikrarının yaşandığı ülkelerde } \\
\text { ekonomik büyüme ile enflasyon arasında pozitif } \\
\text { ilişki vardır. }\end{array}$ \\
\hline Romer & 1996 & $\begin{array}{c}1884-1994 \\
(1941-1951 \\
\text { Hariç })\end{array}$ & EKK & $\begin{array}{l}\text { ABD'de yüzde } 0,1 \text { oranında enflasyon artışı } \\
\text { ekonomik büyümenin yüzde } 1 \text { oranında artmasına } \\
\text { neden olmaktadır. }\end{array}$ \\
\hline $\begin{array}{l}\text { Mallik ve } \\
\text { Chowdhury }\end{array}$ & 2001 & 1961-1997 & $\begin{array}{l}\text { Johansen } \\
\text { Eşbütünleşme Testi } \\
\text { ve Hata Düzeltme } \\
\text { Modeli (ECM) }\end{array}$ & $\begin{array}{l}\text { Hindistan (1961-1997), Bangladeş (1974-1997), } \\
\text { Pakistan (1957-1997) ve Sri Lanka'da (1966-1997) } \\
\text { enflasyon ve ekonomik büyüme arasında pozitif } \\
\text { yönlü ilişki vardır. }\end{array}$ \\
\hline Yakışık & 2007 & $1995-2005$ & EKK & $\begin{array}{l}\text { Kırgızistan'da yüzde } 11 \text { oranında enflasyon artış1 } \\
\text { ekonomik büyümenin yüzde } 1 \text { oranında artmasına } \\
\text { neden olmaktadır. }\end{array}$ \\
\hline $\begin{array}{l}\text { Ahmad ve } \\
\text { Joyia }\end{array}$ & 2012 & 1971-2011 & $\begin{array}{l}\text { Granger Nedensellik } \\
\text { ve EKK }\end{array}$ & $\begin{array}{c}\text { Pakistan'da yüzde } 1 \text { oranındaki enflasyon artışı } \\
\text { GSYİH'nın yüzde } 0,45 \text { oranında artmasını } \\
\text { sağlamaktadır. }\end{array}$ \\
\hline Mahmoud & 2015 & $1990-2013$ & EKK & $\begin{array}{l}\text { Moritanya'da enflasyon ve ekonomik büyüme } \\
\text { arasında pozitif bir ilişki vardır. }\end{array}$ \\
\hline
\end{tabular}

Enflasyon ve ekonomik büyüme arasındaki ilişkiye yönelik olarak Mundell, bu iki değişken arasında pozitif ilişki olduğunu savunmuştur. Mundell'e göre, enflasyonda ortaya çıan bir artış bireylerin servetlerinde azalışa neden olacak ve bu nedenle, enflasyon öncesi servet dengesine ulaşabilmeyi amaçlayan bireylerin tasarruf eğilimlerini artırması söz konusu olacaktır. Sonuçta faiz oranlarında ortaya çıkan düşüş, yatırımların artmasına neden olarak ekonomik büyümeye pozitif katkı sağlayacaktır (Erçel, 1999: 2). Mundell-Tobin etkisi olarak isimlendirilen yaklaşımda, enflasyon sonucunda para tutmanın maliyeti artıracaktır. Bu durumda bireyler riskten kaçınmak ve reel gelir seviyesini korumak isteyerek portföy kararlarını sermaye lehine değiştirecek ve sonuçta sermaye birikimi artarken reel faiz oranları düşecek ve büyüme hızlanacaktır. Diğer yandan paranın değer saklama ve tasarruf fonksiyonu dışında başka amaçlar için de talep edilmesinin mümkün olması Mundell-Tobin yaklaşımına eleştirileri artırmakta ve bu görüş enflasyon-büyüme arasındaki ilişkinin negatif olduğunu savunmaktadır. Finansal piyasalara ek olarak alternatif yatırım imkânlarının da olduğu ekonomilerde bireylerin cari harcamalarından ayrı olarak alternatif yatırım araçlarından getiri elde etmek amacıyla da para talep etmeleri mümkündür. Ancak finansal piyasaların gelişmiş olduğu ekonomilerde para talebi değer saklama amacı da taşıdığından dolayı enflasyon sonucunda bireyler portföy kararlarını değiştirmeyecektir. Sidrauski (1967)'nin genişletilmiş modelinde para arzının reel ekonomik faaliyetleri etkilemediği ve enflasyonun Mundell-Tobin etkisinde savunulduğu gibi ekonomik büyümeyi pozitif etkilemediği, sermaye birikiminin enflasyondan negatif etkilendiği sonucuna ulaşılmış ve geleneksel neoklasik iktisadi görüsse göre ekonomik büyümenin kaynağı enflasyondan değil verimlilik artışı olarak görülmüş̧ür (Terzi ve Oltulular, 2006: 2).

1970'li yıllarda ortaya çıkan petrol krizleri sonucunda durgunluk ve enflasyonun bir arada görüldüğü stagflasyonist süreç yaşanmaya başlamış ve ortaya çıan bu durum dönüştürülmüş Phillips eğrisinde ifade edilen enflasyon ve işsizlik ilişkisinin geçerliliğini yitirmesine neden olmuştur. Bu da Phillips eğrisine göre, enflasyonun artırılması durumunda işsizliğin azalacağı yani ekonomik büyümenin artacağı iddiasının geçerliliğini kaybetmesine neden olmuştur (Romer, 2006: 252-253). Bu durumun ortaya çıkmasındaki en önemli sebep 1970'li yıllardan itibaren artan enflasyon oranlarına rağmen işsizlikte bir iyileşme 
yaşanmamasından kaynaklanmaktadır. Diğer yandan, enflasyonun olduğu bir ekonomide büyümenin bu durumdan olumlu etkilenmesi bir yana enflasyon sonucunda ortaya çıkan olumsuz beklentiler, kaynak dağılımının bozulması, tüketimdeki düşüş, sermaye maliyetlerinin artması ve belirsizlik artışı gibi sebepler nedeniyle enflasyonun ekonomik büyümeyi engellediğini ifade eden çalışmalar da oldukça fazladır (Berber ve Artan, 2004: 3).

Diğer yandan içsel büyüme modelleri ele alındığında ise bu modeller neoklasiklerden farklı olarak beşeri sermayeyi de sermaye kavramına dâhil etmektedir. Buna göre tüm sermaye modellerinin getiri oranının dengeli bir büyüme oranını sağlayacak şekilde olması gerekmektedir. İçsel büyümenin ele alındığı Lucas (1980), Lucas ve Stokey (1987), McCallum ve Goodfiriend (1987)'in çalışmalarında enflasyon yaşanan ekonomilerde enflasyonun sermaye üzerinde vergi etkisi oluşturmasından dolayı gerek fiziki gerekse de beşeri sermaye getirilerinin azalacağı kabul edilmektedir. Sonuçta ekonomik büyümenin enflasyondan negatif etkilenmesi durumu ortaya çıkacaktır (Gokal ve Hanif, 2004: 16-17).

\section{Tablo 2: Ekonomik Büyümenin Enflasyondan Negatif Etkilendiğini Savunan Çalışmalar}

\begin{tabular}{|c|c|c|c|c|}
\hline Yazar(lar) & Yil & Analiz Dönemi & Yöntem & Sonuç \\
\hline Edwards & 1982 & $1952-1974$ & EKK & $\begin{array}{l}\text { Brezilya (1952-1974) ve Şili'de (1952-1970) } \\
\text { enflasyon büyümeyi negatif etkilemektedir. }\end{array}$ \\
\hline Barro & 1995 & $1960-1990$ & Panel Veri & $\begin{array}{l}\text { Yaklaşık } 100 \text { ülkede enflasyondaki yüzde 1'lik } \\
\text { bir artış kişi başı GSYIH'nın yüzde } 2 \text {-3 } \\
\text { oranında azalmasına neden olmaktadır. }\end{array}$ \\
\hline $\begin{array}{l}\text { Chari, Jones } \\
\text { ve Manuelli }\end{array}$ & 1996 & $1960-1987$ & EKK & $\begin{array}{c}\text { Enflasyondaki yüzde } 10 \text { 'luk bir artış ekonomik } \\
\text { büyümeyi yüzde } 0.5 \text { oranında azaltmaktadır. }\end{array}$ \\
\hline $\begin{array}{l}\text { Kim ve } \\
\text { Willett }\end{array}$ & 2000 & $1963-1992$ & Panel Veri & $\begin{array}{c}23 \text { gelişmiş OECD ülkesi ve } 27 \text { gelişmekte olan } \\
\text { ülkede enflasyon ekonomik büyümeyi negatif } \\
\text { etkilemektedir. }\end{array}$ \\
\hline $\begin{array}{l}\text { Faria ve } \\
\text { Carneiro }\end{array}$ & 2001 & 1980:1-1995:7 & $\begin{array}{l}\text { Vektör Otoregresif } \\
\text { Model (VAR) }\end{array}$ & $\begin{array}{l}\text { Brezilya'da kısa dönemde enflasyon ekonomik } \\
\text { büyümeyi olumsuz etkilemektedir. }\end{array}$ \\
\hline Hodge & 2006 & $1950-2002$ & EKK & $\begin{array}{l}\text { Güney Afrika'da enflasyon ekonomik büyümeyi } \\
\text { negatif etkilemektedir. }\end{array}$ \\
\hline Yapraklı & 2007 & $\begin{array}{l}\text { 1987:Q1- } \\
\text { 2007:Q1 }\end{array}$ & $\begin{array}{l}\text { Granger Nedensellik } \\
\text { ve Eşbütünleşme }\end{array}$ & $\begin{array}{c}\text { Türkiye'de ekonomik büyüme enflasyondan } \\
\text { negatif etkilenmektedir }\end{array}$ \\
\hline Türkekul & 2007 & $\begin{array}{l}\text { 1988:Q1- } \\
\text { 2007:Q1 }\end{array}$ & $\begin{array}{l}\text { Granger Nedensellik } \\
\text { ve VAR }\end{array}$ & $\begin{array}{c}\text { Enflasyon ekonomik büyümeyi negatif yönde } \\
\text { etkilemektedir. Ayrica enflasyondan ekonomik } \\
\text { büyümeye doğru tek yönlü bir nedensellik } \\
\text { ilişkisi mevcuttur. }\end{array}$ \\
\hline Taban & 2008 & 1970-2006 & $\begin{array}{l}\text { Gecikmesi Dağıtılmış } \\
\text { Otoregresif Model } \\
\text { (ARDL) }\end{array}$ & $\begin{array}{l}\text { Enflasyonun büyüme üzerinde uzun ve kısa } \\
\text { dönemde negatif etkileri vardır. }\end{array}$ \\
\hline
\end{tabular}

Fiyatlar genel seviyesinde yaşanan sürekli artışları ifade eden enflasyonun ekonomi üzerindeki etkisi oranın yüksekliğine bağlı olarak da değişebilmektedir. Yüzde 2-3 dolaylarında yaşanacak bir enflasyonun ekonomi üzerinde pozitif etkiler oluşturması muhtemel olmakla birlikte yüzde 100 gibi yüksek oranlarda ortaya çıkacak hiperenflasyonist ortam ekonomi üzerinde sarsıc1 etkiler meydana getirecektir. Diğer yandan makul enflasyon oranını ne olduğu da ülkelerin gelişmişlik seviyelerine göre farklılık arz etmektedir. Gelişmiş ülkelerde yüzde 4'e kadar yaşanan konjonktürel dalgalanmalar olağan ve makul görülmekle birlikte aynı oranların gelişmekte olan ülkelerde yakalanması çok da kolay olmamaktadır. İşte bu nedenle enflasyonun 
ekonomik büyüme üzerindeki etkisi incelenirken belirli bir eşik değer belirlenmesi gerektiğini savunan çalışmalara da literatürde sıkça rastlanılmaktadır. Tablo 3'te verilen bilgiler değerlendirildiğinde enflasyon oranının yaklaşık yüzde 6 ile 10 seviyesinin altında gerçekleşmesi durumunda ekonomik büyüme üzerinde enflasyonun pozitif etkisi olduğu sonucuna ulaşıldığı görülmektedir.

\section{Tablo 3: Ekonomik Büyüme Enflasyon İlişkisini Belirli Bir Eşik Değere Göre İnceleyen Çalışmalar}

\begin{tabular}{|c|c|c|c|c|}
\hline Yazar(lar) & Yil & Analiz Dönemi & Yöntem & Sonuç \\
\hline Tun Wai & 1959 & $1938-1954$ & Panel Veri & $\begin{array}{l}31 \text { gelişmekte olan ülkede yüzde } 13 \text { oranının } \\
\text { altındaki enflasyon oranları ekonomik büyümeyi } \\
\text { pozitif etkilemektedir. }\end{array}$ \\
\hline $\begin{array}{l}\text { Thirwall ve } \\
\text { Barton }\end{array}$ & 1971 & $1951-1967$ & Panel Veri & $\begin{array}{c}\text { Gelişmiş ülkelerde yüzde } 8 \text { 'den daha az enflasyon } \\
\text { oranları ekonomik büyümeyi pozitif etkilerken, } \\
\text { GOÜ'lerde yüzde 10'un üzerindeki enflasyon } \\
\text { oranlarından ekonomik büyüme negatif } \\
\text { etkilenmektedir. }\end{array}$ \\
\hline Sarel & 1996 & $1970-1990$ & Panel Veri & $\begin{array}{l}87 \text { ülkede enflasyonun yüzde } 8 \text { 'in üzerinde } \\
\text { gerçekleşmesi durumunda enflasyon ekonomik } \\
\text { büyümeyi negatif yönde etkilemektedir. }\end{array}$ \\
\hline $\begin{array}{l}\text { Khan ve } \\
\text { Senhadji }\end{array}$ & 2001 & 1960-1998 & $\begin{array}{c}\text { Doğrusal Olmayan } \\
\text { EKK }\end{array}$ & $\begin{array}{c}\text { Gelişmiş ülkelerde enflasyon oranının yüzde } 3 \text {, } \\
\text { GOÜ’lerde ise yüzde } 12 \text { 'nin üzerinde olması } \\
\text { durumunda ekonomik büyüme negatif } \\
\text { etkilenmektedir. }\end{array}$ \\
\hline $\begin{array}{l}\text { Caporin ve } \\
\text { Di Maria }\end{array}$ & 2002 & 1979-1997 & Panel Veri & $\begin{array}{c}\text { Enflasyonun yüzde } 10 \text { 'un altında olduğu ülkelerde } \\
\text { enflasyon oranındaki bir birimlik artış ekonomik } \\
\text { büyümeyi } 0.12 \text { oranında enflasyon oranının yüzde } \\
10 \text { ile } 30 \text { arasında olduğu ülkelerde enflasyon } \\
\text { oranındaki bir birimlik artışın ekonomik büyümeyi } \\
\text { yüzde } 0.05 \text { oranında ve enflasyonun yüzde } 30 \text { 'un } \\
\text { üstünde olduğu ülkelerde ise } 0.0004 \text { oranında } \\
\text { azaltmaktadır. }\end{array}$ \\
\hline $\begin{array}{l}\text { Ahmed ve } \\
\text { Mortaza }\end{array}$ & 2005 & $1980-2005$ & $\begin{array}{l}\text { Johansen } \\
\text { Eşbütünleşme Testi ve } \\
\text { (ECM) }\end{array}$ & $\begin{array}{c}\text { Bangladeş'te enflasyonun yüzde 6'y1 geçmesi } \\
\text { durumunda ekonomik büyüme negatif } \\
\text { etkilenmektedir. }\end{array}$ \\
\hline $\mathrm{Li}$ & 2006 & 1961-2004 & Panel Veri & $\begin{array}{l}\text { GOÜ'lerde enflasyonun yüzde } 14 \text { 'ün altında } \\
\text { olması durumunda büyüme pozitif etkilenmekte, } \\
\text { yüzde } 14 \text { ile } 28 \text { arasında olmas durumunda negatif } \\
\text { etkilenmekte ve yüzde } 28 \text { 'in üzerinde } \\
\text { gerçekleşmesi durumunda ise enflasyonun } \\
\text { ekonomik büyüme üzerindeki etkisi azalmakla } \\
\text { birlikte negatif etki devam etmektedir. }\end{array}$ \\
\hline $\begin{array}{l}\text { Aydın, Esen } \\
\text { ve Bayrak }\end{array}$ & 2016 & $1992-2013$ & Panel Veri & $\begin{array}{l}\text { Kazakistan, Azerbaycan, Özbekistan, Kırgızistan } \\
\text { ve Türkmenistan'da yüzde 7,97’nin üzerindeki } \\
\text { enflasyon oranları ekonomik büyümeyi negatif } \\
\text { etkilerken bu değerin altındaki enflasyonun } \\
\text { ekonomik büyüme üzerinde pozitif etkisi vardır. }\end{array}$ \\
\hline
\end{tabular}

Enflasyon ile ekonomik büyüme arasındaki ilişkiye dair bir diğer görüş ise enflasyon ile ekonomik büyüme arasında istatistiki açıdan anlamlı bir ilişkinin olmaması durumudur. $\mathrm{Bu}$ sonuca literatürde ilk olarak Fischer tarafından 1993 yılında yapılan çalışma ile ulaşılmıştır (Fischer, 1993: 485-511). 
Friedman (1968) ve Phelps (1967 ve 1968) tarafindan Phillips eğirişine bekleyişlerin de dâhil edilmesiyle birlikte kısa dönemde enflasyon ile işsizlik arasındaki ilişkinin istikrarlı olmadığı ve uzun dönemde iki değişken arasında herhangi bir ilişki olmadığ argümanı geliştirilmiştir. $\mathrm{Bu}$ argüman çerçevesinde enflasyon oranının artması sonucunda enflasyon beklentisinin de artması ve sonuçta Phillips eğrisinin yukarı kayması söz konusu olacaktır. Bu durumda beklenen enflasyon oranı arttıkça alternatif Phillips eğrileri oluşacaktır. Friedman'a göre para arzı artırılarak işsizliğin düşürülebilmesi mümkün olsa da bir süre sonra fiyat artış beklentilerinin enflasyonla uyum sağlaması sonucunda Phillips eğrisi yukarı kayacaktır ve işsizlik başlangıçtaki seviyesine geri dönecektir. Sonuçta enflasyon ve işsizlik yani ekonomik büyüme arasındaki "değiş̧-tokuş" ilişkisi geçicidir ve uzun dönemde herhangi bir "değiş-tokuş" söz konusu değildir.

\section{Tablo 4: Ekonomik Büyüme ile Enflasyon Arasında İlişki Olmadığını Savunan Çalışmalar}

\begin{tabular}{|c|c|c|c|c|}
\hline Yazar(lar) & Yll & Analiz Dönemi & Yöntem & Ülkeler \\
\hline $\begin{array}{l}\text { Bullard ve } \\
\text { Keating }\end{array}$ & 1995 & $1960-1992$ & VAR & 58 Gelişmiş ve Gelişmekte Olan Ülke \\
\hline Chowdhury & 2002 & $1950-1997$ & Teorik & Endonezya \\
\hline Mughal vd. & 2012 & $1960-2010$ & $\begin{array}{l}\text { Genelleştirilmiş } \\
\text { Otoregresif Koşullu } \\
\text { Değişen Varyans } \\
\text { (GARCH) }\end{array}$ & Endonezya, Tayland, Filipinler ve Malezya \\
\hline Topçu & 2017 & 2006:Q1-2017:Q2 & $\begin{array}{c}\text { Granger } \\
\text { Nedensellik ve } \\
\text { Johansen } \\
\text { Eşbütünleşme }\end{array}$ & $\begin{array}{c}\text { Ekonomik büyümeden enflasyona doğru tek } \\
\text { yönlü nedensellik ilişkisi vardır. Seriler } \\
\text { arasında eşbütünleşme ilişkisi tespit } \\
\text { edilememiştir. }\end{array}$ \\
\hline
\end{tabular}

Enflasyon-ekonomik büyüme ilişkisine ilişkin literatür bir bütün olarak incelendiğinde ilk olarak söz konusu ilişkinin yönü ve varlığına ilişkin bir görüş birliğinin olmadığı net bir şekilde göze çarpmaktadır. Esasen 1970'li yıllardan önceki dönemi de kapsayan çalışmalar genel olarak düşük enflasyonun yaşandığı dönemlerde ekonomik büyümenin pozitif etkilendiğini ortaya koymaktadır. Ancak 1970'lerden sonra enflasyon oranlarında yaşanan aşırı artışlarla birlikte enflasyonun ekonomik büyümeyi olumsuz etkilediği sonucuna ulaşan çalışmaların sayısının arttığı gözlemlenmektedir. Son yıllarda yapılan çalışmalar da ise enflasyon ve ekonomik büyüme arasındaki ilişkinin daha belirgin bir şekilde ortaya koyulması amacıyla yapısal kırılmaların dikkate alındığı ya da doğrusal olmayan yöntemlerin kullanıldığı çalışmaların artması söz konusu olmuştur. Bu kapsamda enflasyon için belirli bir eşik değer belirlenerek bu eşik değerin altında ya da üstünde ekonomik büyümenin ne şekilde etkilendiği araştırılmıştır. Her ne kadar enflasyon-ekonomik büyüme ilişkisine yönelik çalışmaların farklı sonuçlar ortaya koyduğu görülse de eşik değer kullanılarak yapılan çalışmaların daha tutarlı ve belirgin sonuçlara ulaştığını söylemek mümkündür (Sweidan, 2004: 42-43).

Enflasyon ile ekonomik büyüme arasındaki ilişkinin belirlenmesi uzun yıllardır ekonomi literatüründe araştırma konusu yapılmıştır. Ancak tablolarda görüldüğü üzere enflasyonun ekonomik büyüme üzerindeki etkisinin negatif ya da pozitif olduğu üzerinde ve hatta bir ilişkinin mevcut olup olmadığı yönünde kesin bir görüş birliğine varılamamıştır. Bu nedenle, söz konusu ilişkiyi Türkiye ekonomisi için test etmeye yönelik bu çalışmanın var olan literatüre katkı sağlayacağı düşünülmektedir. 


\section{AMPİRIK BULGULAR}

\subsection{Veri Seti}

Çalışmada ekonomik büyüme ile enflasyon ilișkisinin test edilmesi amacıyla GSYİH ve TÜFE ilişkisi analiz edilmiştir. Türkiye ekonomisinde 2003:Q1-2018:Q1 dönemine ait veriler logaritması alınarak analize dâhil edilmiş ve kullanılan veriler çeyreklik döneme ait olduğundan dolayı hareketli ortalamalar yöntemi (moving average method) ile mevsim hareketlerinden arındırılmıștır. Ekonometrik analizde kullanılan veriler, Türkiye Cumhuriyet Merkez Bankası Elektronik Veri Dağıtım Sistemi’nden (EVDS) elde edilmiştir. Değişkenlerden “GDP” GSYİH'y1, “CPI” ise TÜFE'yi ifade etmektedir.

\subsection{Yöntem}

$\mathrm{Bu}$ çalışmada ilk olarak serilerin durağan olup olmadıklarının tespit edilebilmesi için serilere sirasiyla Augmented Dickey Fuller (ADF) ve Phillips-Perron (PP) birim kök testleri uygulanmıştır. Birim kök testinden sonra Granger nedensellik testi kullanılarak değişkenler arasındaki nedensellik ilişkisi incelenmiştir. Son olarak da derilerin uzun dönemde birlikte hareket edip etmediklerinin belirlenebilmesi için eşbütünleşme testi yapılmıştır.

\subsubsection{Birim Kök Testi}

Serilerin durağanlıklarının sınanması içim ADF ve PP birim kök testleri yapılmıştır. Ampirik çalışmalarda sıklıkla kullanılan ADF birim kök testinin yanı sıra PP testinin de yapılmasının sebebi trend içeren serilerin durağanlığının analizinde PP testinin ADF'den daha güçlü kabul edilmesidir.

Bir serinin durağan olarak değerlendirilebilmesi için serinin beklenen değeri, varyans ve kovaryansının zamandan bağımsız olması gerekmektedir. Bu durum serinin beklenen değeri etrafında dalgalanmasını ve beklenen değer doğrusunu sıklıkla kesmesini ifade etmektedir. Bir serinin cari dönemdeki değerinin, bir önceki dönemden ne derece etkilendiği analiz edilerek zaman serilerinin durağanlığı test edilmektedir. Temsili bir "N" serisi bahsedilen durum şu şekildedir:

$$
N_{t}=p N_{t-1}+u_{t}
$$

Verilen denklemde $I \rho I<1$ olması durumunda geçmiş dönemdeki şoklar etkisini azaltarak sonraki dönemlere aktarılmaktadır. Bu serinin durağan olduğu anlamını taşımaktadır. Ancak $I \rho I$ $=1$ olması durumunda ise önceki dönemlerde ortaya çıkan şoklar sonraki döneme aynen aktarılarak kalıcı hale gelmektedir. Bu da serinin birim köke sahip olduğunu, diğer bir deyişle durağan olmadığını ifade etmektedir. Böyle bir durumda, yani durağan olmayan serilerle yapılacak analizlerde sahte regresyon problemine rastlanılması olası bir durumdur. $\mathrm{Bu}$ nedenle, ilk olarak serilerin birim kök testinin yapılması gerekmektedir. GDP ve CPI serilerinin durağanlıklarının belirlenebilmesi için ADF ve PP birim kök testleri yapılmış ve sonuçlar Tablo 5 'te verilmiştir. 
Tablo 5: ADF ve PP Birim Kök Testleri

ADF Birim Kök Testi

\begin{tabular}{c|cccc}
\cline { 2 - 4 } Değişkenler & Sabitli & Sabitli ve Trendli & Sabitli & Sabitli ve Trendli \\
GDP & $-0.686(0)$ & $-2.404(0)$ & $-0.679(1)$ & $-2.408(2)$ \\
CPI & $-0.010(0)$ & $-2.635(0)$ & $-0.043(12)$ & $-2.732(3)$ \\
D(GDP) & $-8.307(0)$ & $-8.238(0)$ & $-8.307(0)$ & $-8.238(0)$ \\
D(CPI) & $-8.082(0)$ & $-8.022(0)$ & $-8.448(11)$ & $-8.345(11)$ \\
Kritik Değerler & $\% 1:-3.54$ & $\% 1:-4.12$ & $\% 1:-3.54$ & $\% 1:-4.11$ \\
& $\% 5:-2.91$ & $\% 5:-3.48$ & $\% 5:-2.91$ & $\% 5:-3.48$ \\
& $\% 10:-2.59$ & $\% 10:-3.17$ & $\% 10:-2.59$ & $\% 10:-3.17$
\end{tabular}

Not: ADF testinde parantez içindeki değerler SIC'a göre belirlenen uygun gecikme uzunluklarını göstermektedir. PP testinde ise parantez içindeki değerler Bandwith değerlerini göstermekte olup, bu değerler Newey-West'e göre belirlenen uygun gecikme uzunluklarını yansıtmaktadır.

Analizde kullanılan zaman serilerinin düzey değerlerinde durağan olması durumu $I(0)$ olarak ifade edilmektedir. Ancak serinin birim köke sahip olması ve belirli bir dereceden farkı alındıktan sonra durağanlaşması söz konusu ise seri hangi dereceden farkı alınınca durağanlaşıyorsa o farktan durağan olarak ifade edilmektedir. Diğer bir deyişle, serinin düzey değerinde birim köke sahip olması ve $(n)$ dereceden fark1 alındığında durağan hale gelmesi durumunda, söz konusu seri $I(n)$ şeklinde gösterilmektedir (Tarı, 2002:373-375).

Yapılan ADF ve PP birim kök testi sonuçlarına göre, yüzde 1 anlamlılık düzeyinde sabitli hem de sabitli ve trendli modelde her iki değişken için hesaplanan " $\tau$ " istatistikleri kritik değerlerden büyük çıkmış ve serilerin birim köke sahip olduğunu ifade eden $H_{0}$ hipotezi reddedilememiştir. Bu durum serilerin düzey değerlerinde durağan olmadığını göstermiştir. Diğer yandan söz konusu değişkenler birinci farkları alındığında durağan hale gelmiştir. Sonuçta gerek ADF gerekse de PP test sonuçlarına göre değişkenlerin I(1) olduğu görülmektedir.

\subsubsection{Nedensellik Testi}

Değişkenler arasındaki ilişkinin yönünün kesin olarak belirlenmesi oldukça güç olduğundan dolayı söz konusu ilişkinin tespit edilebilmesi için Granger (1969) nedensellik testi kullanılmaktadır. Granger tarafından geliştirilen bu testte değişkenlerin karşılıklı etkileşimleri eşanlı olarak belirlenmekte ve bağımlı-bağımsız değişken ayrımı olmamaktadır.

GDP ve CPI değişkenleri arasındaki Granger nedensellik ilişkisinin verilen modellerle belirlenmesi mümkündür.

$$
\begin{aligned}
G D P_{t} & =\sum_{i=1}^{m} \delta_{i} G D P_{t-i}+\sum_{i=1}^{m} \gamma_{i} C P I_{t-i}+u_{t} \\
C P I_{t} & =\sum_{i=1}^{m} \beta_{i} C P I_{t-i}+\sum_{i=1}^{m} \theta_{i} G D P_{t-i}+u_{t}
\end{aligned}
$$


GDP ve CPI serilerine ilişkin verilen denklemlerde değişkenler arasında çift yönlü ilişkinin varlığından bahsedebilmek için $\gamma_{i}$ ve $\theta_{i}$ 'den her ikisinin de sıfırdan farklı bir değer alması gerekmektedir. Diğer yandan, sadece bir tanesinin sıfira eşit olması durumunda tek yönlü nedensellik söz konusu iken, her ikisinin de sıfira eşit olması durumunda herhangi bir nedensellik ilişkisinden bahsetmek mümkün değildir. Ayrıca seriler arasında tek yönlü ya da karşılıklı nedensellik ilişkisi tespit edilmiş olsa dahi söz konusu etkinin pozitif ya da negatif yönlü olduğuna dair Granger nedensellik testi bilgi vermemektedir (Granger, 1969; Gujarati, 2011). Değişkenler arasındaki nedensellik ilişkisinin tespitinde $H_{0}$ hipotezi nedensellik ilişkisinin olmadığını ifade ederken, $H_{l}$ alternatif hipotezi ise nedensellik ilişkisinin varlığını ifade etmektedir. Tablo 6'da GDP ve CPI değişkenlerine ilişkin nedensellik testi sonuçları verilmişstir.

Tablo 6: Granger Nedensellik Testi

\begin{tabular}{ccc|cccc}
\multicolumn{9}{c}{ F İstatistiği } & $\begin{array}{c}\text { Olasılık } \\
\text { Değeri }\end{array}$ & Sonuç & Karar \\
\hline GDP & $\rightarrow \quad$ CPI & 4.04088 & 0.0066 & $H_{0}$ Red & $\begin{array}{c}\text { GSYİH'dan TÜFE'ye doğru bir } \\
\text { nedensellik ilişkisi vardır. }\end{array}$ \\
CPI $\rightarrow$ GDP & 1.12786 & 0.3546 & $H_{0}$ Kabul & $\begin{array}{c}\text { TÜFE'den GSYİH'ya doğru bir } \\
\text { nedensellik ilişkisi yoktur. }\end{array}$
\end{tabular}

Not: Optimum gecikme uzunluğu LR, FPE ve AIC kriterleri baz alınarak 4 olarak belirlenmiştir.

Tablo 6'da nedensellik testi sonuçları incelendiğinde CPI'nin bağımlı değişken olarak ele alınması durumunda değişkenler arasında nedensellik ilişkisi olmadığını ifade eden H0 hipotezi reddedilmiş ve GSYIHH'dan TÜFE'ye doğru bir nedensellik ilişkisi tespit edilmiştir. Ancak aynı durum GDP'nın bağımlı değişken olarak ele alındığında geçerli olmayıp, TÜFE'den GSYİH'ya doğru herhangi bir nedensellik ilişkisi bulunamamıştır.

\subsubsection{Eşbütünleşme Testi}

Durağan olmayan değişkenlerle yapılan regresyon sonuçlarının genellikle sahte regresyona yol açtığı düşünülmektedir. Serileri durağan hale getirebilmek için farkları alındığında ise serinin geçmiş dönemde maruz kaldığı şokların etkileri ve serilerin karakteristik özellikleri yok edilmektedir. Bu nedenle seriler arasında gerçek uzun dönem ilişkisini ortaya çıkarmak güçleşmektedir. Bu durumda değişkenler arasındaki eşbütünleşme ilişkisinin testi önem kazanmaktadır. Değişkenler arasında eşbütünleşme varsa bu durumda değişkenlerin düzey değerleri ile yapılan regresyon sonuçları sahte değil gerçek regresyon sonuçları olacaktır.

Eşbütünleşme analizi ilk olarak Engle-Granger (1987) tarafindan tek denklemli olarak geliştirildikten sonra ilerleyen dönemde Johansen (1988) ve Johansen-Juselius (1990) tarafından çok denklemli şekilde ele alınmıştır. Birden fazla sayıda bağımsız değişkenin kullanıldığı analizlerde kullanılan ve VAR (vektör otoregresif) temelli olan Johansen eşbütünleşme testi açıklayıcı değişken sayısının iki ve daha fazla olduğu durumlarda Engle-Granger eşbütünleşme testine göre güçlü kabul edilmektedir. Bu çalışmada kullanılan değişkenler GDP ve CPI'dan (bir bağımlı bir bağımsız değişken) oluştuğundan dolayı tekli eşbütünleşme testi kullanılacaktır. 
Tablo 7: Engle-Granger Eşbütünleşme Testi

\begin{tabular}{l|cccc} 
& Tau-İstatistiği & Olasılık & Z-İstatistiği & Olasılık \\
\hline GDP & -2.442934 & 0.3160 & -10.58672 & 0.2974 \\
CPI & -2.340747 & 0.3625 & -10.00363 & 0.3319
\end{tabular}

Engle-Granger eşbütünleşme testi sonuçlarının olasılık değerin bakılarak yorumlanması mümkündür. Olasılık değerinin 0.05 'ten küçük olması durumunda seriler arasında eşbütünleşme ilişkisinin olmadığını ifade eden $\mathrm{H} 0$ hipotezi reddedilir ve seriler arasında eşbütünleşme olduğuna karar verilir. Tablo 7'deki sonuçlara bakıldığında olasılık değerlerinin 0.05 'ten büyük olduğu görülmektedir. Bu durumda seriler arasında eşbütünleşmenin olmadığı şeklinde kurulan $\mathrm{H}_{0}$ hipotezinin kabul edilmesi söz konusudur. Bu sonuç Türkiye'de GSYİH ve TÜFE serilerinin uzun dönemde birlikte hareket etmedikleri ve seriler arasında uzun dönemli bir ilişkinin olmadığ anlamına gelmektedir. Seriler arasında bir eşbütünleşme tespit edilemediğinden dolayı serilerin düzey değerleriyle yapılacak analizlerin sahte regresyon barındırması olası bir durumdur. Diğer yandan serilere ait Johansen eşbütünleşme testi sonuçları da ekte verilmiştir ve Johansen eşbütünleşme sonuçlarına göre de herhangi bir koentegrasyon tespit edilememiştir.

\section{SONUÇ}

Türkiye ekonomisinde 2000'li y1llarda enflasyon ile ekonomik büyüme arasındaki ilişkinin tespit edilmesi amacıyla 2003:Q1-2018:Q1 dönemine ait zaman serileri kullanılmıştır. Enflasyon-ekonomik büyüme ilişkisinin Türkiye ekonomisi için sınanmasında nedensellik testi ve eşbütünleşme analizi yapılmıştır. Analizin yapılabilmesi için ilk TÜFE ve GSYİH'ya ilişkin seriler birim kök testine tabi tutulmuş ADF (Genişletilmiş Dickey- Fuller) ve PP (PhillipsPerron) testleri sonucunda her iki değiş̧kenin de düzey değerlerinde durağan olmağ 1 ve birinci dereceden farkı alındığında durağan hale geldikleri yani $I(1)$ oldukları görülmüştür. Daha sonra seriler arasındaki nedensellik ilişkisinin tespit edilebilmesi için Granger nedensellik analizi yapılmıştır. Yapılan nedensellik testinde milli gelirden enflasyona doğru tek yönlü bir nedensellik ilişkisi olduğu görülmüştür. Bu sonuca göre enflasyondaki değişmeler milli geliri etkilemezken, milli gelirde ortaya çıkan değişmelerin fiyat istikrarı üzerinde etkisi olduğunu ortaya koymuştur. Ancak nedensellik testi ilişkinin şiddeti ve yönünün belirlenmesinde herhangi bir bilgi vermemektedir. Bu sebepten dolayı da analize eşbütünleşme testi ile devam edilmiştir. Eşbütünleşme analizi yapılmasının bir diğer nedeni yapılan durağanlık testinde serilerin her ikisinin de $I(1)$ olduklarının görülmesidir. Bilindiği üzere durağan olmayan serilerle yapılan analizlerin aşırı parametreleşme sorununa sahip olması çok büyük olasılıktır. Ancak seriler arasında eşbütünleşme ilişkisinin tespit edilmesi durumunda değişkenlerin düzey değerleriyle yapılan analizlerde herhangi bir sahte regresyon sorunu olmayacaktır. Çalışmada bir bağımlı bir bağımsız değişken olduğundan dolayı yapılan tekli Granger eşbütünleşme testinde değişkenler arasında eşbütünleşmeye rastlanılmamıştır. Bu durum serilerin uzun dönemde birbirinden etkilenmediklerini ve bağımsız hareket ettiklerini göstermektedir. Diğer yandan Johansen eşbütünleşme analizi sonuçları da bu bulguları desteklemektedir.

Çalışma sonuçları incelendiğinde elde edilen bulgular Bullard ve Keating (1995), Chowdhury (2002), Mughal vd. (2012) ve Topçu (2017) ile benzerlik arz etmektedir.

Enflasyon ile ekonomik büyüme ilişkisini Türkiye ekonomisi açısından inceleyen çalışmalara bakıldığında analizlerin genellikle yüksek enflasyon dönemine yoğunlaştığı görülmektedir. $\mathrm{Bu}$ nedenle elde edilen sonuçlar genellikle enflasyon ve ekonomik büyüme arasında ters yönlü bir ilişki olduğunu ortaya koymaktadır. Ancak bu çalışmada ele alınan 
dönemin düşük enflasyonun yaşandığı ve görece yüksek büyüme oranlarının yakalandığı 2000’li yıllarla sınırlı tutulduğu göz önüne alındığında enflasyon-ekonomik büyüme ilişkisinin farklı sonuçlar ortaya koyması muhtemeldir. Sonuçta söz konusu dönem için Türkiye'de ekonomik büyümenin sağlanmasında enflasyonun bir araç olarak kullanılamayacağına ulaşılmıştır. Bu da 1970'li y1llardan itibaren ortaya koyulan enflasyonun ekonomik büyümenin sağlanmasında bir araç olmadığı fikrini destekler niteliktedir.

\section{KAYNAKÇA}

Abel, B. A. ve Bernanke, S. B. (2005). Macroeconomics. 5th Edition, Pearson Education Inc., Pearson Addison Wesley.

Ahmad, N. ve Joyia, U.T.S. (2012). The relationship between inflation and economic growth in Pakistan: an econometric approach. Asian Journal of Research in Business Economics and Management, 2(9), 38-48.

Ahmed, S. ve Mortaza, M. (2005). Inflation and economic growth in Bangladesh: 1981-2005. Working Paper, No: 0604.

Aydın, C., Esen, Ö. ve Bayrak, M. (2016). Inflation and economic growth: a dynamic panel threshold analysis for Turkish Republics in transition process. Procedia - Social and Behavioral Sciences, 229, 196-205.

Barro, R.J. (1995). Inflation and economic growth. Bank of England Quarterly Bulletin, 35, 166-176.

Berber, M. ve Artan, S. (2004). Türkiye'de enflasyon - ekonomik büyüme ilişkisi. Atatürk Üniversitesi İktisadi ve İdari Bilimler Fakültesi Dergisi, 18(3-4), 103-117.

Bruno, M. ve Easterly, W. (1996). Inflation and growth: in search of a stable relationship. Federal Reserve Bank of St. Louis Review, 78(3), 139-146.

Bullard, J. ve Keating, J.W. (1995). The long-run relationship between inflation and output in postwar economies. Journal of Monetary Economics, 36(3), 477-496.

Caporin, M. and Di Maria, C. (2002). Inflation and growth: some panel data evidence. http://www.greta.it/wp/02.09.PDF, Retrieved on July 25, 2018

Chari, V.V., Lary., E.J. ve Manuelli, R. (1996). Inflation, growth and financial intermediation. Federal Reserve Bank of St. Louis Review, 78(3), 41-58.

Chowdhury, A. (2002). Does inflation affect economic growth? The relevance of the debate for Indonesia. Journal of Asia Pacific Economy, 7(1), 20-34.

Edwards, S. (1982). The relation between growth and inflation in Latin America. Working Paper. UCLA Department of Economics, No: 235.

Engle, R.F. ve Granger, C.W.J. (1987). Cointegration and error correction: representation, estimation and testing. Econometrica, 55, 251-276.

Erçel, G. (2000). Türkiye'de enflasyon ve büyüme ilişkisi genel bir değerlendirme. http://www.tcmb.gov.tr/wps/wcm/connect/0e1115ea-f510-4dad-a9343f80956cfbd8/15enflasyon.pdf?MOD=AJPERES\&CACHEID=ROOTWORKSPACE-0e1115ea-f510-4dad-a9343f80956cfbd8-m3fBeN1, (09.10.2018).

Faria, J.R. and Carneiro, F.G. (2001). Does high inflation affect growth in the long and short run?. Journal of Applied Economics, 4(1), 89-105.

Fischer, S. (1993). The role of macroeconomic factors in growth, Journal of Monetary Economics, 32(3), 485-511.

Friedman, M. (1968). The Role of Monetary Policy. American Economic Review, 58, 1-17.

Gokal, V. ve Hanif, S. (2004). Relationship between inflation and economic growth. Economics Department Reserve Bank of Fiji, Working Paper. No: 2004/04.

Granger, C.W.J. (1969). Investigating causal relations by econometric models and cross-spectral methods. Econometrica, 37(3), 424-438.

Gujarati, D. (2011). Econometrics by example. PaIgrave, MacmiIan.

Hodge, D. (2006). Inflation and growth in South Africa. Cambridge Journal of Economics, 30(2), 163-180. 
Johansen, S. ve Juselius, K. (1990). Maximum likelihood estimation and inference on cointegration with applications to the demand for money. Oxford Bulletin of Economics and Statistics, 52(2), 169-210.

Johansen, S. (1988). Statistical analysis of cointegration vectors. Journal of Economic Dynamics and Control, 12(2-3), 231-254.

Khan, S.M. ve Senhadji, A.S. (2001). Threshold effects in the relationship between inflation and economic growth. IMF Staff Papers, 48(1), 1-21.

Kim, S. ve Willett, T.D. (2000). Is the negative correlation between inflation and economic growth realian analysis of the effects of the oil supply shocks?. Applied Economics Letters, 7(3), 141-147.

Li, M. (2006). Inflation and economic growth: threshold effects and transmission mechanisms. http://economics.ca/2006/papers/0176.pdf, Retrieved on June 25, 2018.

Lucas, R.E. (1973), Some international evidence on output-inflation tradeoffs, The American Economic Review, 63(3), 326-334.

Mahmoud, L.O.M. (2015). Consumer price index and economic growth: a case study of Mauritania 1990 -2013. Asian Journal of Empirical Research, 5(2), 16-23.

Mallik, G. and Chowdhury, A. (2001). Inflation and economic growth: evidence from four south Asian countries. Asia-Pasific Development Journal, 8(1), 123-135.

Mughal, F.A., Aslam, N., Jabbar, M.A. ve Ullah, W. (2012), Inflation, inflation uncertainty and output growth, are they related? A study on south East Asian economies 1960-2010. Journal of Basic and Applied Scientific Research, 2(6), 6108-6114.

Phelps, E. S. (1967). Phillips Curves, expectations of inflation, and optimal unemployment over time. Economica 34, 254-281.

Phelps, E. S. (1968). Money-wage dynamics and labor-market equilibrium. Journal of Political Economy, 76, 678711.

Phillips, A.W. (1958). The relation between unemployment and the rate of change of money wages in the United Kingdom, 1861-1957. Economica, 25(100), 283-99.

Romer, C.D. (1996). Inflation and the growth rate of output. Working Paper, National Bureau of Economic Research, No: 5575.

Romer, D. (2006). Advanced Macroeconomics. 3rd Edition, The McGraw-Hill Companies, New York.

Sarel M. (1996). Nonlinear effects of inflation on economic growth. IMF Staff Papers, 43(1), 199-215.

Samuelson, P.A. ve R.M. Solow. (1960). Analytical aspects of anti-inflation policy. American Economic Review, 50(2), 177-194.

Sidrauski, M. (1967). Rational choice and patterns of growth in a monetary economy. American Economic Review, 57(2), 534-544.

Sweidan, O.D. (2004). Does inflation harm economic growth in Jordan? An econometric analysis for the period 19702000. International Journal of Applied Econometrics and Quantitative Studies, 1-2, 41-66.

Taban, S. (2008). Türkiye'de enflasyon-ekonomik büyüme ilişkisi: sınır testi yaklaşımı. TiSK Akademi, 2008-1, 145167

Tarı, R. (2002). Ekonometri, Alfa Yayınları, İstanbul.

Terzi, H. ve Oltulular, S. (2006). Enflasyon-büyüme sürecinde sabit sermaye yatırımları. Atatürk Üniversitesi İktisadi ve Idari Bilimler Dergisi, 20(1), 1-18.

Thirlwall, A.P. ve Barton, C.A. (1971). Inflation and growth: the international evidence, Banco Nazionale del Lavoro Quarterly Review, 98, 263-275.

Topçu, E. (2017). Enflasyon oranı-ekonomik büyüme ilişkisi: Türkiye örneği. Nevşehir Hacı Bektaş Veli Üniversitesi SBE Dergisi, 7(2), 180-191.

Tun Wai U. (1959). The relation between inflation and economic development: a statistical inductive, IMF Staff Papers, 7, 202-209.

Türkekul, B. (2007). Türkiye'de enflasyon-büyüme ilişkisi: tarım sektörü itibariyle ekonometrik bir analiz. Ege Üniversitesi Ziraat Fakültesi Dergisi, 44 (1), 163-175. 
Yakışı, H. (2007). Relationship between inflation and economic growth in the Kyrgyz Republic. Sosyo-Ekonomi, 2007-2, 12-28.

Yaprakl1, S. (2007). Enflasyon ve ekonomik büyüme arasındaki ilişki: Türkiye için eş-bütünleşme ve nedensellik testleriyle bir analiz. Atatürk Üniversitesi Sosyal Bilimler Enstitüsü Dergisi, 10(2), 287-300.

\section{Ek 1 - Johansen Eşbütünleşme Testi Sonuçları}

\begin{tabular}{cccc} 
Hipotez & Trace İstatistiği & Kritik Değer (\%5) & Olasılık \\
\hline Hiç Yok & 16.86210 & 25.87211 & 0.4253 \\
\hline En Fazla 1 & 3.608932 & 12.51798 & 0.7977 \\
& & & Olasılık \\
Hipotez & Max-Eigen İstatistiği & Kritik Değer (\%) & 0.3080 \\
Hiç Yok & 13.25317 & 19.38704 & 0.7977 \\
\hline En Fazla 1 & 3.608932 & 12.51798 &
\end{tabular}

